\title{
ferfings Merke.
}

2H מter Band.

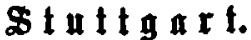

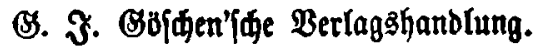

1874. 
2. Gofbutbrudeti 34 Guttenberg (Carl Grüninger) in Stuttgart. 